Review

\title{
The Role of Cyclooxygenase-2 in Colorectal Cancer
}

\author{
Juan Sheng ${ }^{1^{*}}$, Hong Sun ${ }^{2^{*}}$, Fu-Bing $\mathrm{Yu}^{1^{*}}$, Bo Li ${ }^{3}$, Yuan Zhang ${ }^{\bowtie}$ and Ying-Ting Zhu ${ }^{4}$ \\ 1. Department of Gastroenterology, the Second People's Hospital of Yunnan Province, Kunming, Yunnan 650021, China \\ 2. The First Affiliated Hospital of Nanjing Medical University, Nanjing, Jiangsu 210029, China \\ 3. Department of General Surgery, The Second People's Hospital of Yunnan Province, Kunming, Yunnan 650021, China \\ 4. Tissue Tech Inc, Miami, Florida 33032, USA \\ *The first three authors contribute equally to this work. \\ $\square$ Corresponding author: Yuan Zhang, M.D and PH.D., Scientist, or Ying-Ting Zhu, Ph.D. Senior Scientist, Basic Research, TissueTech, Inc., 7300 Corporate \\ Center Drive, Suite B, Miami, FL 33126, USA. Telephone: (786) 456-7632; Fax: (305) 274-1297; E-mail: yzhu@tissuetechinc.com \\ (c) The author(s). This is an open access article distributed under the terms of the Creative Commons Attribution License (https://creativecommons.org/licenses/by/4.0/). \\ See http://ivyspring.com/terms for full terms and conditions.
}

Received: 2020.01.31; Accepted: 2020.04.14; Published: 2020.04.27

\begin{abstract}
Colorectal cancer is the third common cancer in this world, accounting for more than 1 million cases each year. However, detailed etiology and mechanism of colorectal cancer have not been fully understood. For example, cyclooxygenase-2 (COX-2) and its product prostaglandin $\mathrm{E}_{2}\left(\mathrm{PGE}_{2}\right)$ have been closely linked to its occurrence, progression and prognosis. However, the mechanisms on how COX-2 and PGE $_{2}$-mediate the pathogenesis of colorectal cancer are obscure. In this review, we have summarized recent advances in studies of pathogenesis and control in colorectal cancer to assist further advances in the research for the cure of the cancer. In addition, the knowledge gained may also guide the audiences for reduction of the risk and control of this deadly disease.
\end{abstract}

Key words: cancer, colon, cyclooxygenase-2, invasion, prostaglandin

\section{Introduction}

Colorectal cancer (CRC) is a common fatal cancer in developed countries such as USA [1, 2], accounting for more than 1 million cases each year [3] and 700,000 deaths [4]. Most recently, it is reported that colorectal cancer ranks fourth in the world's deadly cancer, accounting approximately 900,000 deaths yearly, due to increase of aging populations, obesity and lack of exercise [5]. In fact, colorectal cancer (CRC) is the second most frequent deadly cancer in the United State. The proposed causative factors include but not limited to genetic mutations and chronic inflammation. Until recently, it is still not known what causes CRC because of complexity of the etiology of CRC.

Etiologically, colon cancer is caused by spread of colorectal cancer cells to other parts of the body. The causative factors include genetic alterations, overexpression of Cytooxgenase-2 (COX-2), smoking, drinking of alcohol, harmful diet and lack of physical exercises [6-8]. Among those ricking factors, the occurrence of the cancer is closely linked to overexpression of COX-2, which has been noted in most of CRC $[9,10]$. Increased levels of COX-2 mRNA and protein are found in the great majority of colorectal adenocarcinomas compared with levels in adjacent histologically normal mucosa [9]. A causal role for COX-2 in colorectal carcinogenesis is demonstrated in vivo in a murine model, and the biologic effects of upregulation of the enzyme are mediated predominantly through increased $\mathrm{PGE}_{2}$ production [11]. Therefore, many researchers have been trying to use COX-2 inhibitors such as nonsteroidal anti-inflammatory drugs (NSAID) and COX-2 inhibitors (COXIB) to control this deadly disease.

In this review, we summarize recent advances in understanding of COX-2 signaling in etiology of CRC. We also try to renew our interest in prevention and control of colorectal cancer by NSAID and COXIB.

\section{COXs}

COXs are important regulators of angiogenesis, inflammation and carcinogenesis. COXs are located at luminal side in the endoplasmic reticulum and 
associated with the nuclear envelope [12], containing three isoforms, that is, COX-1, COX-2 and COX-3 [13]. COX-1 is a housekeeping enzyme to meet the basic requirement for prostaglandins (PGs) $[13,14]$. COX-3 is a variant of COX-1 mainly within central nervous system $[15,16]$. In contrast, COX-2 is an inducible isoform [17] in normal tissue such as colorectal, kidney, reproductive organs and stomach [18, 19]. However in carcinogenesis, COX2 can be constantly upregulated $[17,20]$, for example, adenocarcinoma, squamous cell carcinoma, cholangiocarcinoma, endometrial carcinoma and hepatocellular carcinoma $[21,22]$.

Many factors, for example, DCA, IL-1 $\beta$ and LPS might promote expression of COX-2 moderately in normal fibroblasts (NFs), but profoundly in cancer-associated fibroblasts (CAFs) [23]. Our results have clearly demonstrated that COX-2 is enhanced by DCA, HGF and IL-1 $\beta$ [24-27]. As a result, Prostaglandin $\mathrm{E}_{2}\left(\mathrm{PGE}_{2}\right)$ production is greatly promoted, and such promotion increases proliferation and invasiveness of epithelial cancer cells [25, 27, 28]. Nevertheless, COX-2 inhibitors such as NS398 may decrease proliferation and invasiveness of colorectal cancer cells by overexpression of COX-2 and its product PGE2 [25, 27, 28].

\section{Stromal Cells in Colorectal Carcinogenesis}

Stromal cells, for example, fibroblasts actively participate in carcinogenesis [29]. We have reported that fibroblasts from the stromal compartment play a pivotal role in COX-2 signalling and carcinogenesis $[25-27,30]$. As shown previously, cancer-associated fibroblasts (CAFs) may promote epithelial ovarian cancer [31]. Cytokines, for example, IL-1 $\beta$, Tumor Necrosis Factor- $\alpha$ (TNF- $\alpha$ ) and other compounds, for instance, deoxycholic acid (DCA) stimulates COX-2 expression, which enhances PGE2 production in colorectal fibroblasts [32-38]. In addition, COX-2 expression and $\mathrm{PGE}_{2}$ production in CAFs from biopsies of colorectal cancer tissues are much greater than those from normal fibroblasts (NFs) [33]. Therefore, we should focus on the mechanism how COX-2 expression and PGE2 production is medicated and how such findings are linked to progression and invasion of colorectal cancers.

\section{PGEs and Their Receptors}

COX-2 is an enzyme regulating $\mathrm{PGE}_{2}$ within our body [39]. Prolonged $\mathrm{PGE}_{2}$ increase is usually a sign of inflammation, cancer genesis and spread. COX-2 mediates biosynthesis and release of prostaglandins using arachidonic acid (AA) as the substrate [39]. In other words, this enzyme first converts arachidonic acid into prostaglandin $\mathrm{G}_{2}$ and prostaglandin $\mathrm{H}_{2}$, and then synthesize prostaglandin $\mathrm{D}_{2}, \mathrm{E}_{2}, \mathrm{~F}_{2} \mathrm{a}, \mathrm{I}^{2}$ and thromboxane $\mathrm{A}_{2}$, exerts their actions through the cognate G-protein-coupled receptors (GPCRs) [39].

Prostaglandins are active lipid compounds which have multiple hormone functions to participate in inflammation and progression of colon cancer [40, 41].

Prostaglandin signaling is involved in the progression of many diseases including chronic diseases such as cancer, suggesting prostaglandins are indeed associated with regulation of both acute and chronic inflammation [9]. The main form of prostaglandin involved in colorectal cancer is $\mathrm{PGE}_{2}$. $\mathrm{PGE}_{2}$ can act on the receptors, for example, EP1, EP2, EP3, and EP4 to induce $\mathrm{PGE}_{2}$ signal cascade, leading to changes of intracellular calcium, cAMP and some inflammatory factors. As a result, physiological or pathological processes follow [23, 42]. Recent investigations support that $\mathrm{PGE}_{2}$ may enhance progression of colorectal cancer [41, 43, 44], and EP4 is a therapeutic target for cancer therapy $[45,46]$. COX-2 derived $\mathrm{PGE}_{2}$ can also contribute to tumor development through several mechanisms including inhibition of apoptosis. However, the mechanisms by which $\mathrm{PGE}_{2}$ regulates apoptosis are still largely unknown. The $\mathrm{EP}_{2}$ and $\mathrm{EP}_{4}$ receptors mediate their activities through cAMP production. Suppression of apoptosis has been seen in intestinal cells by cAMP through the induction of the IAP family member-inhibitor of apoptosis 2 (IAP-2) [47, 48] Therefore, it is wise to investigate the hypothesis that anti-apoptotic effects of $\mathrm{PGE}_{2}$ are mediated through cAMP, which results in the induction of the IAP family member c-IAP2.

\section{The cellular distribution of COX-2 and $\mathrm{PGE}_{2}$}

The sub-epithelial tissue lies immediately underneath the epithelial layer. The mesenchyme of a tissue lies immediately underneath the epithelium. That is, fibroblasts are the predominant cells of the sub-epithelial layer. Interestingly, the cellular site of COX-2 upregulation in the earliest intestinal cancer tissue is sub-epithelial, and not epithelial.

In fact, recent studies have demonstrated that fibroblasts play a far more varied role than you anticipate. The cells express many receptors for cytokines and hormones and modulate intestinal secretary responses to inflammatory mediators by releasing $\mathrm{PGE}_{2}$.

The sub-epithelial site of inducible COX-2 expression in early murine intestinal adenomas conflicts with alternative evidence that, rather, upregulation of this enzyme occurs in colorectal 
epithelial cells [49]. To reconcile the issue, we hypothesize that in normal and premalignant colorectal tissue, mesenchymal cells are the principal source of COX-2 expression. Nevertheless, once malignant transformation has occurred, the enzyme is also expressed in the epithelium. The question, then, arises of which mesenchymal cells might express COX-2 in nonmalignant colorectal tissue.

\section{COX-2 signaling is a marker for tumorigenesis}

COX-2 is a short-lived rate-limiting enzyme [19, 50]. It converts arachidonic acid (AA) to prostaglandins (PGs) and thromboxanes [51]. A major PG product of COX-2 is $\mathrm{PGE}_{2}$, which may regulate angiogenesis, immunity and tumorigenesis [52-54]. In carcinogenesis, COX-2 may be uncontrollably elevated, transcriptionally or post-transcriptionally $[55,56]$. Therefore, increase of COX-2 expression is a marker for tumor diagnosis, which is associated with patients' survival rate [17, 57-60]. The significant roles of COX2 signaling has closely been correlated various types of cancer as reported [13, 18, 61-63]. Recent research suggests that $\mathrm{PGE}_{2}$ may indeed significantly promote development and progression of colorectal cancer [41, 43, 44]. COX-2 is also critical to promote metastasis [64] participating in metastasis to bone [65], brain [66], liver [67] and lymph nodes [68]. COX-2-medicated Factors like IL-11 is associated with cancer metastasis [65]. Metastasis occurs when cancer cells invade extracellular matrix, blood vessels and finally lymphatics [69]. Growing evidence has indicated that COX-2 signaling plays important roles in colorectal cancer metastasis. For instance, transactivation of EGFR by Src can promote the invasion mediated by $\mathrm{PGE}_{2}$ [70]. $\mathrm{PGE}_{2}$ may also promote invasion of colorectal cancer cells through PI3K [71]. In addition. COX-2 overexpression can affect adhesion properties of intestinal cells [72] and promote matrix metalloproteinase activity and thus cancer invasion [73]. Inhibition of COX-2 can antagonize colorectal metastasis in human [74] and in mouse [75] models. c-Met, hepatocyte growth factor receptor, may be transactivated by $\mathrm{PGE}_{2}$ via EGFR in case of colorectal cancer [76] which is linked with loss of cell-cell contact and invasion [77]. The supporting evidence includes co-existence of $\beta$-catenin and c-Met at invasive edge of colorectal tumor [76]. COX-2 may promote carcinogenesis via $\beta 1$-integrin $[78,79]$. In all, these reports indicate that COX-2 indeed actively participate in tumorigenesis. Interestingly, a recent article demonstrates that COX-2 in addition to cancer epithelial cells is also expressed in the cancer stroma cells and in the stroma cells of the adjacent normal tissue and that prostaglandin E2 (the final product of arachidonic acid catalysis by COX-2) is significantly more profoundly expressed in the adjacent normal tissue compared to cancer tissue $(p<0.002)$ [80], suggesting that the role of COX-2 appears to be involved in the early stages of progression of the oncogenetic mechanism of CRC, initially affecting the host (tumor microenvironment) of the tumor in normal cells and later tumor epithelial cells of the tumor itself. The authors suggest that treatment should be given to prevent CRC rather than to suppress this progression especially to colorectal tumors in which the expression was found to be greatest.

\section{COX-2-promoted carcinogenesis is related to angiogenesis}

Suppression of COX-2 inhibits corneal neovascularization in colorectal cancer [81] by promoting production of angiogenic vascular endothelial growth factor (VEGF), a potent angiogenic growth factor [82]. In fact, overexpression of COX-2 promotes overexpression of VEGF, which induces tumor angiogenesis in Apc/COX-2 knockout mouse model [83]. Deletion of COX-2 gene may result in reduced growth in tumor xenografts and vascular density [84], probably via activation of Rac1 and Cdc42 [85]. In all, evidence indicates that COX-2 may induce uncontrollable angiogenesis in colorectal cancer.

\section{Cytokines and other compounds regulating COX-2 signaling}

Recent reviews have summarized recent advances in the role of COX-2 and prostaglandin $E_{2}$ in the pathogenesis of colorectal cancer $[18,61,62]$. A report suggests that $\mathrm{PGE}_{2}$ signaling mediates chronic inflammation in the colorectal microenvironment [86]. Cytokines and other compounds such as DCA, IL-1 $\beta$, tumor necrosis factor a (TNF- $\alpha$ ) and lipopolysaccharide (LPS) may promote expression of COX-2 mRNA and protein in human colorectal fibroblasts, profoundly in cancer-associated fibroblasts (CAF) [25-27]. When stimulated with the pro-inflammatory cytokines interleukin (IL)-1 $\beta$ or TNF- $\alpha$, orbital fibroblasts express high levels of COX-2 and synthesized correspondingly high levels of $\mathrm{PGE}_{2}$ [87]. Powell and colleagues described a population of specialized sub-epithelial "myofibroblasts" with pleiotropic capabilities, including the ability to modulate intestinal secretory responses to inflammatory mediators by releasing $\mathrm{PGE}_{2}$ [88]. We have noted that IL- $1 \beta$ or TNF- $\alpha$ promotes production of $\mathrm{PGE}_{2}$ by as much as 25-fold in human colorectal fibroblasts we obtained from colonoscopies [30]. Equivalent or greater increases in COX-2 mRNA and 
protein expression preceded the increases in $\mathrm{PGE}_{2}$ synthesis. We also report that inducible COX-2 expression is substantially more robust in cancer-associated than normal colorectal fibroblasts [28]. IL-1 $\beta$ may stimulate expression of COX-2 and production of $\mathrm{PGE}_{2}$ synthesis in cancer-associated fibroblasts by activating COX-2 promoter activities. The rate at which COX-2 mRNA decays can be dramatically retarded in vitro by $\mathrm{PGE}_{2}$ [89]. We believe that this mechanism may be an important contributing factor to the enhanced $\mathrm{PGE}_{2}$ synthesis of cancer-associated colorectal fibroblasts. Those reactions are probably through activation of protein kinase C (PKC) [90], suggesting that stromal cells also play an important role in colorectal carcinogenesis. Such activation may be through enhanced production of $\mathrm{PGE}_{2}$, and as a result, mediating proliferation, invasion and apoptosis of colorectal cancer cells [25, 27]. Such activation of COX-2 is closely associated with increased proliferation and invasiveness in human colorectal epithelial cancer cells [25, 27, 28], because COX-2 inhibitor (NS398) or PKC inhibitor (Bisindoylmalemide I, BIM or Staurosporine, STA) can dramatically down-regulate the proliferation and invasiveness of colorectal epithelial cancer cells [25, 27, 28]. Combination of PKC and COX-2 inhibitors can synergistically inhibit melanoma metastasis [91]. We have noted that IL-1 $\beta$ and TNF- $\alpha$ induce mRNA overexpression of COX-2 and promote production of PGE2 in human colorectal fibroblasts, especially in CRC-associated strains [27, 92]. We have also noted that DCA strongly promotes COX-2 expression and PGE2 production in colorectal cancer fibroblasts in vitro [25]. Inducible nitric oxide synthetases (iNOS) are also probably involved in the carcinogenesis of colorectal cancer because activation of iNOS by LPS is associated with activation of COX-2 signaling, and inhibition of iNOS by iNOS inhibitor 1400W or iNOS siRNA may nullify production of nitric oxide (NO) and $\mathrm{PGE}_{2}$ [26]. NO may also promote mRNA production of COX-2 from colorectal cancer cells, for example, HCA7 and HCT116 [56]. We have reported that deoxycholic acid (DCA) also dramatically promotes COX-2 expression in colorectal cancer fibroblasts in vitro [25]. The expression and activity of iNOS and COX-2 may also be induced by LPS in those fibroblasts, resulting in increased $\mathrm{NO}$ production and COX-2 expression [26]. DCA is also a transcriptional activator of COX-2 in esophageal cancer cells [93].

\section{Nonsteroidal Anti-inflammatory drugs}

For decades, a significant progress is achieved to discoveries of effective drugs for CRC. One of those is nonsteroidal anti-inflammatory drugs (NSAID) which inhibit COX-2 [94-96]. NSAID includes aspirin, ibuprofen, naproxen, nimesulide and sulindac acid. Different NASID may act via different signaling pathways. For example, ibuprofen, indomethacin and naproxen can bind the activity site of COX-2, inhibit its activity reversibly, while aspirin acetylates the activity site of COX-2, attenuating its activity irreversibly. Some NSAID drugs for example, Aspirin, can facilitate the effect of COX-2 inhibitors for treatment of stage III colorectal cancer [97]. In fact, Aspirin may reduce colon cancer mortality in women by as much as $50 \%[9,98,99]$. Recently, a hybrid drug KSS19, a combination of NSAID refecoxib and cis-stilbene, has been found to be a potent COX-2 inhibitor, which inhibits colon cancer cell growth effectively [100].

Although COX-2 inhibitors are promising candidates for treatment of colorectal cancer, some concerns for treatment of colorectal cancer by COX inhibitors have been raised. For example, an elevated risk of myocardial infarction may be linked to its usage [101]. In addition, the extended use of nonselective NSAID is also associated with a number of pathological symptoms, for example, abdominal pain, dyspepsia, gastritis, gastrointestinal bleeding nausea, and perforation of gastroduodenal ulcers [102]. Therefore, no major clinical trials of those inhibitors were successfully completed due to concerns of their adverse effect. Anyway, NSAID are effective in certain degrees for prevention and treatment of colorectal cancer. For example, a randomized trial demonstrates that NSAID are preventive for colorectal cancer on the patients with polyps [103, 104]. According to the results of large-scale trials, including the Adenomatous Polyp Prevention on Vioxx trial [105], the Adenoma Prevention with Celecoxib trial [104], the Prevention of Colorectal Sporadic Adenomatous Polyps trial [106] and colon polyp prevention trial [107], COXIB are effective for prevention of recurrence from sporadic colon cancer. Regular consumption of NSAID is also helpful for lowing the risk of colorectal, breast, lung and prostate cancer [108]. In all, it is still unknown how to prevent the potential risk when COX inhibitors are used for treatment of colorectal cancer.

To decrease the risk from COX inhibitors, many researchers have used low dose of COX inhibitors with other NSAID drugs that target other critical pathways in carcinogenesis. For example, combination of celecoxib with erlotinib (an EGFR tyrosine kinase inhibitor) is more effective to control polyp formation using an ApcMin/+ mice model and to inhibit cancer growth in a xenograft model [109]. Celecoxib with erlotinib treatment is more effective for treatment of the advanced non-small cell lung 
cancer [110]. A 5-lipoxygenase inhibitor may inhibit resistant tumor cells to SC-236 (COX inhibitor) and tumor growth in a breast cancer animal model [111]. Combined treatment of celecoxib with peroxisome proliferators-activated receptor- $\gamma$ agonist is better than either alone in a mouse breast cancer model [112]. Combination of aromatase inhibitors with celecoxib is better for patients suffering from metastatic breast cancer than either alone [113]. Therefore, we should reconsider the prospect of COX inhibitors for treatment of colon cancer.

\section{Perspective}

From previous work on certain types of cancer, COX-2 may be is a key indicator to predict cancer prognosis. Along with the product $\mathrm{PGE}_{2}, \mathrm{COX}-2$ is a major stimulator for progression of colorectal cancer. $\mathrm{Up}$ to now, the reports from basic and clinical investigations have shown that inhibition of $\mathrm{PGE}_{2}$ synthesis by specific COX-2 inhibitors, for example, nonsteroidal anti-inflammatory drugs (NSAIDs) may decrease the risk and improve prognosis of carcinogenesis of various types of cancer including colorectal cancer $[64,114-120]$. Therefore, we need to strive forward to work out a protocol for successful use of COX-2 inhibitors in clinical applications to colorectal cancers and other types of cancer as well.

\section{Summary}

To summarize, the scientific basis for the current proposal, outlined above, is as follows: fibroblasts from mesenchymal (stromal) layer are the major target of cytokines such as IL1 $\beta$ and TNFa; fibroblasts are the predominant mesenchymal cells; fibroblasts from nonneoplastic colorectal tissue are a potent source of COX-2 expression, which is firmly established as an important factor in colorectal carcinogenesis. We believe that the investigation of COX-2 gene regulation is vital for control of this disease.

\section{Abbreviation}

CAF: cancer-associated fibroblast; COX: Cyclooxygenase; CRC: colorectal cancer; DCA: deoxycholic acid; EGF: epithelial growth factor; EP, FP, IP, TP and DP: prostanoid receptors; IL-1 $\beta$ : Interleukin $1 \beta$; iNOS: inducible nitric oxide synthase; LPS: lipopolysaccharide; NF: normal fibroblast; NO: nitric oxide; NSAID: nonsteroidal anti-inflammatory drug; p53: tumor protein p53; PG: prostaglandin; PKA: cAMP-dependent protein kinase; PKC: protein kinase C; TNF: tumor necrosis factor.

\section{Acknowledgements}

\section{Author Contributions}

Juan Sheng, Hong Sun, Fubing Yu and Bo Li participated in collecting the information and drafting the manuscript. Yuan Zhang and Yingting Zhu and finalize the manuscript.

\section{Competing Interests}

The authors have declared that no competing interest exists.

\section{References}

1. Jemal A, Siegel R, Xu J, Ward E. Cancer statistics, 2010. CA Cancer JClin. 2010; 60: 277-300.

2. Siegel RL, Miller KD, Jemal A. Cancer statistics, 2015. CA Cancer J Clin. 2015; 65: 5-29.

3. Cunningham D, Atkin W, Lenz HJ, Lynch HT, Minsky B, Nordlinger B, et al. Colorectal cancer. Lancet. 2010; 375: 1030-47.

4. Lozano R, Naghavi M, Foreman K, Lim S, Shibuya K, Aboyans V, et al. Global and regional mortality from 235 causes of death for 20 age groups in 1990 and 2010: a systematic analysis for the Global Burden of Disease Study 2010. Lancet. 2012; 380: 2095-128.

5. Dekker E, Tanis PJ, Vleugels JLA, Kasi PM, Wallace MB. Colorectal cancer. Lancet. 2019; 394: 1467-80.

6. Fodde R. The APC gene in colorectal cancer. EurJCancer. 2002; 38: 867-71.

7. Watson AJ, Collins PD. Colon cancer: a civilization disorder. Dig Dis. 2011; 29: 222-8.

8. Jawad N, Direkze N, Leedham SJ. Inflammatory bowel disease and colon cancer. Recent Results Cancer Res. 2011; 185: 99-115.

9. Kargman SL, O'Neill GP, Vickers PJ, Evans JF, Mancini JA, Jothy S. Expression of prostaglandin $\mathrm{G} / \mathrm{H}$ synthase-1 and -2 protein in human colon cancer. Cancer Res. 1995; 55: 2556-9.

10. Negi RR, Rana SV, Gupta V, Gupta R, Chadha VD, Prasad KK, et al. Over-Expression of Cyclooxygenase-2 in Colorectal Cancer Patients. Asian Pac J Cancer Prev. 2019; 20: 1675-81.

11. Oshima M, Dinchuk JE, Kargman SL, Oshima H, Hancock B, Kwong E, et al. Suppression of intestinal polyposis in Apc delta716 knockout mice by inhibition of cyclooxygenase 2 (COX-2). Cell. 1996; 87: 803-9.

12. Claria J. Cyclooxygenase-2 biology. Curr Pharm Des. 2003; 9: 2177-90.

13. Pang LY, Hurst EA, Argyle DJ. Cyclooxygenase-2: A Role in Cancer Stem Cell Survival and Repopulation of Cancer Cells during Therapy. Stem Cells Int. 2016; 2016: 2048731.

14. Soh JW, Weinstein IB. Role of COX-independent targets of NSAIDs and related compounds in cancer prevention and treatment. Prog Exp Tumor Res. 2003; 37: 261-85.

15. Sarkar FH, Adsule S, Li Y, Padhye S. Back to the future: COX-2 inhibitors for chemoprevention and cancer therapy. Mini Rev Med Chem. 2007; 7: 599-608.

16. Kis B, Snipes JA, Isse T, Nagy K, Busija DW. Putative cyclooxygenase-3 expression in rat brain cells. J Cereb Blood Flow Metab. 2003; 23: 1287-92.

17. Gurram B, Zhang S, Li M, Li H, Xie Y, Cui H, et al. Celecoxib Conjugated Fluorescent Probe for Identification and Discrimination of Cyclooxygenase-2 Enzyme in Cancer Cells. Anal Chem. 2018; 90: 5187-93.

18. Su CW, Zhang Y, Zhu YT. Stromal COX-2 signaling are correlated with colorectal cancer: A review. Crit Rev Oncol Hematol. 2016; 107: 33-8.

19. Obermoser V, Baecker D, Schuster C, Braun V, Kircher B, Gust R. Chlorinated cobalt alkyne complexes derived from acetylsalicylic acid as new specific antitumor agents. Dalton Trans. 2018; 47: 4341-51.

20. Raj V, Bhadauria AS, Singh AK, Kumar U, Rai A, Keshari AK, et al. Novel 1,3,4-thiadiazoles inhibit colorectal cancer via blockade of IL-6/COX-2 mediated JAK2/STAT3 signals as evidenced through data-based mathematical modeling. Cytokine. 2018.

21. Mortezaee K. Human hepatocellular carcinoma: Protection by melatonin. J Cell Physiol. 2018; 233: 6486-508.

22. Dannenberg AJ, Lippman SM, Mann JR, Subbaramaiah K, DuBois RN. Cyclooxygenase-2 and epidermal growth factor receptor: pharmacologic targets for chemoprevention. J Clin Oncol. 2005; 23: 254-66.

23. Zhu Y, Hua P, Lance P. Cyclooxygenase-2 expression and prostanoid biogenesis reflect clinical phenotype in human colorectal fibroblast strains. Cancer Res. 2003; 63: 522-6.

24. Chen HC, Zhu YT, Chen SY, Tseng SC. Selective Activation of p120(ctn)-Kaiso Signaling to Unlock Contact Inhibition of ARPE-19 Cells without Epithelial-Mesenchymal Transition. PLoSOne. 2012; 7: e36864.

25. Zhu $Y, Z$ hu $M$, Lance P. Stromal COX-2 signaling activated by deoxycholic acid mediates proliferation and invasiveness of colorectal epithelial cancer cells. BiochemBiophysResCommun. 2012; 425: 607-12.

26. Zhu Y, Zhu M, Lance P. iNOS signaling interacts with COX-2 pathway in colonic fibroblasts. ExpCell Res. 2012; 318: 2116-27. 
27. Zhu Y, Zhu M, Lance P. IL1beta-mediated Stromal COX-2 signaling mediates proliferation and invasiveness of colonic epithelial cancer cells. ExpCell Res. 2012; 318: 2520-30.

28. Zhu Y, Hua P, Rafiq S, Waffner EJ, Duffey ME, Lance P. Ca2+- and PKC-dependent stimulation of PGE2 synthesis by deoxycholic acid in human colonic fibroblasts. AmJPhysiol GastrointestLiver Physiol. 2002; 283: G503-G10.

29. Nomura T, Lu R, Pucci ML, Schuster VL. The two-step model of prostaglandin signal termination: in vitro reconstitution with the prostaglandin transporter and prostaglandin 15 dehydrogenase. Mol Pharmacol. 2004; 65: 973-8.

30. Kim EC, Zhu Y, Andersen V, Sciaky D, Cao HJ, Meekins H, et al. Cytokine-mediated PGE2 expression in human colonic fibroblasts. AmJPhysiol. 1998; 275: C988-C94.

31. Chillar AJ, Karimi P, Tang K, Ruan KH. An agonist sensitive, quick and simple cell-based signaling assay for determination of ligands mimicking prostaglandin E2 or E1 activity through subtype EP1 receptor: Suitable for high throughput screening. BMC Complement Altern Med. 2011; 11: 11.

32. Breyer MD, Breyer RM. Prostaglandin receptors: their role in regulating renal function. Curr Opin Nephrol Hypertens. 2000; 9: 23-9.

33. Mutoh M, Watanabe K, Kitamura T, Shoji Y, Takahashi M, Kawamori T, et al. Involvement of prostaglandin $\mathrm{E}$ receptor subtype $\mathrm{EP}(4)$ in colon carcinogenesis. Cancer Res. 2002; 62: 28-32.

34. Watanabe K, Kawamori T, Nakatsugi S, Ohta T, Ohuchida S, Yamamoto H, et al. Role of the prostaglandin E receptor subtype EP1 in colon carcinogenesis. Cancer Res. 1999; 59: 5093-6.

35. Pozzi A, Yan X, Macias-Perez I, Wei S, Hata AN, Breyer RM, et al. Colon carcinoma cell growth is associated with prostaglandin E2/EP4 receptor-evoked ERK activation. J Biol Chem. 2004; 279: 29797-804.

36. Fujino $\mathrm{H}, \mathrm{Xu} \mathrm{W}$, Regan JW. Prostaglandin E2 induced functional expression of early growth response factor-1 by EP4, but not EP2, prostanoid receptors via the phosphatidylinositol 3-kinase and extracellular signal-regulated kinases. J Biol Chem. 2003; 278: 12151-6.

37. Regan JW. EP2 and EP4 prostanoid receptor signaling. Life Sci. 2003; 74: 143-53.

38. Rojas A, Gueorguieva P, Lelutiu N, Quan Y, Shaw R, Dingledine R. The prostaglandin EP1 receptor potentiates kainate receptor activation via a protein kinase $C$ pathway and exacerbates status epilepticus. Neurobiol Dis. 2014; 70: 74-89.

39. Chandrasekharan NV, Simmons DL. The cyclooxygenases. Genome Biol. 2004; 5: 241.

40. Castellone MD, Teramoto $\mathrm{H}$, Williams BO, Druey KM, Gutkind JS. Prostaglandin E2 promotes colon cancer cell growth through a Gs-axin-beta-catenin signaling axis. Science. 2005; 310: 1504-10.

41. Fujino H, Seira N, Kurata N, Araki Y, Nakamura H, Regan JW, et al. Prostaglandin E2-stimulated prostanoid EP4 receptors induce prolonged de novo prostaglandin E2 synthesis through biphasic phosphorylation of extracellular signal-regulated kinases mediated by activation of protein kinase A in HCA-7 human colon cancer cells. Eur J Pharmacol. 2015; 768: 149-59.

42. Prescott SM, Fitzpatrick FA. Cyclooxygenase-2 and carcinogenesis. BiochimBiophysActa. 2000; 1470: M69-M78.

43. Fujino H. The Roles of EP4 Prostanoid Receptors in Cancer Malignancy Signaling. Biol Pharm Bull. 2016; 39: 149-55.

44. Thomas SS, Makar KW, Li L, Zheng Y, Yang P, Levy L, et al. Tissue-specific patterns of gene expression in the epithelium and stroma of normal colon in healthy individuals in an aspirin intervention trial. Genom Data. 2015; 6: 154-8.

45. Lin MC, Chen SY, He PL, Herschman H, Li HJ. PGE2 /EP4 antagonism enhances tumor chemosensitivity by inducing extracellular vesicle-mediated clearance of cancer stem cells. Int J Cancer. 2018.

46. Lala PK, Nandi P, Majumder M. Roles of prostaglandins in tumor-associated lymphangiogenesis with special reference to breast cancer. Cancer Metastasis Rev. 2018.

47. Crowley-Weber CL, Payne CM, Gleason-Guzman M, Watts GS, Futscher B, Waltmire CN, et al. Development and molecular characterization of HCT-116 cell lines resistant to the tumor promoter and multiple stress-inducer, deoxycholate. Carcinogenesis. 2002; 23: 2063-80.

48. Nishihara H, Kizaka-Kondoh S, Insel PA, Eckmann L. Inhibition of apoptosis in normal and transformed intestinal epithelial cells by cAMP through induction of inhibitor of apoptosis protein (IAP)-2. Proc Natl Acad Sci U S A. 2003; 100: 8921-6.

49. DuBois RN, Smalley WE. Cyclooxygenase, NSAIDs, and colorectal cancer. J Gastroenterol. 1996; 31: 898-906.

50. Xu W, Huang Y, Zhang T, Zhao L, Fan J, Li L. Cyclooxygenase-2 gene polymorphisms and susceptibility to hepatocellular carcinoma: A meta-analysis based on 10 case-control studies. J Cancer Res Ther. 2018; 14: S105-S13.

51. van der Donk WA, Tsai $\mathrm{AL}$, Kulmacz RJ. The cyclooxygenase reaction mechanism. Biochemistry. 2002; 41: 15451-8.

52. Smith WL, DeWitt DL, Garavito RM. Cyclooxygenases: structural, cellular, and molecular biology. AnnuRevBiochem. 2000; 69: 145-82.

53. Howe LR. Inflammation and breast cancer. Cyclooxygenase/prostaglandin signaling and breast cancer. Breast Cancer Res. 2007; 9: 210

54. Singh-Ranger G, Salhab M, Mokbel K. The role of cyclooxygenase-2 in breast cancer: review. Breast Cancer Res Treat. 2008; 109: 189-98.
55. Ohtsuka J, Oshima H, Ezawa I, Abe R, Oshima M, Ohki R. Functional loss of p53 cooperates with the in vivo microenvironment to promote malignant progression of gastric cancers. Sci Rep. 2018; 8: 2291.

56. Liu $\mathrm{Q}$, Inoue $\mathrm{H}$, Mahendran $\mathrm{R}$. Transcriptional regulation of the COX-2 expression by nitric oxide in colon cancer cell lines. Oncol Rep. 2008; 19: 269-74.

57. Yue X, Nguyen TD, Zellmer V, Zhang S, Zorlutuna P. Stromal cell-laden 3D hydrogel microwell arrays as tumor microenvironment model for studying stiffness dependent stromal cell-cancer interactions. Biomaterials. 2018; 170: 37-48.

58. Gallo O, Masini E, Bianchi B, Bruschini L, Paglierani M, Franchi A. Prognostic significance of cyclooxygenase-2 pathway and angiogenesis in head and neck squamous cell carcinoma. Hum Pathol. 2002; 33: 708-14.

59. Jiao G, Ren T, Lu Q, Sun Y, Lou Z, Peng X, et al. Prognostic significance of cyclooxygenase-2 in osteosarcoma: a meta-analysis. Tumour Biol. 2013; 34: 2489-95.

60. Sicking I, Rommens K, Battista MJ, Bohm D, Gebhard S, Lebrecht A, et al. Prognostic influence of cyclooxygenase-2 protein and mRNA expression in node-negative breast cancer patients. BMC Cancer. 2014; 14: 952

61. Roelofs HM, Te Morsche RH, van Heumen BW, Nagengast FM, Peters WH. Over-expression of COX-2 mRNA in colorectal cancer. BMC Gastroenterol. 2014; $14: 1$.

62. Liu Y, Sun H, Hu M, Zhang Y, Chen S, Tighe S, et al. The Role of Cyclooxygenase-2 in Colorectal Carcinogenesis. Clin Colorectal Cancer. 2017; 16: $165-72$.

63. Liu B, Qu L, Yan S. Cyclooxygenase-2 promotes tumor growth and suppresses tumor immunity. Cancer Cell Int. 2015; 15: 106

64. Greenhough A, Smartt HJ, Moore AE, Roberts HR, Williams AC, Paraskeva C, et al. The COX-2/PGE2 pathway: key roles in the hallmarks of cancer and adaptation to the tumour microenvironment. Carcinogenesis. 2009; 30: 377-86.

65. Singh B, Berry JA, Shoher A, Lucci A. COX-2 induces IL-11 production in human breast cancer cells. J Surg Res. 2006; 131: 267-75.

66. Soto MS, O'Brien ER, Andreou K, Scrace SF, Zakaria R, Jenkinson MD, et al. Disruption of tumour-host communication by downregulation of LFA-1 reduces COX-2 and e-NOS expression and inhibits brain metastasis growth. Oncotarget. 2016; 7: 52375-91.

67. Sorski L, Melamed R, Matzner P, Lavon H, Shaashua L, Rosenne E, et al. Reducing liver metastases of colon cancer in the context of extensive and minor surgeries through beta-adrenoceptors blockade and COX2 inhibition. Brain Behav Immun. 2016; 58: 91-8.

68. Hoing B, Kanaan O, Altenhoff P, Petri R, Thangavelu K, Schluter A, et al. Stromal versus tumoral inflammation differentially contribute to metastasis and poor survival in laryngeal squamous cell carcinoma. Oncotarget. 2018; 9: 8415-26.

69. Weinberg RA. Mechanisms of malignant progression. Carcinogenesis. 2008; 29: 1092-5.

70. He TC, Chan TA, Vogelstein B, Kinzler KW. PPARdelta is an APC-regulated target of nonsteroidal anti-inflammatory drugs. Cell. 1999; 99: 335-45.

71. Sheng H, Shao J, Washington MK, DuBois RN. Prostaglandin E2 increases growth and motility of colorectal carcinoma cells. J Biol Chem. 2001; 276: 18075-81.

72. Tsujii $\mathrm{M}$, DuBois RN. Alterations in cellular adhesion and apoptosis in epithelial cells overexpressing prostaglandin endoperoxide synthase 2. Cell. 1995; 83: 493-501.

73. Tsujii M, Kawano S, DuBois RN. Cyclooxygenase-2 expression in human colon cancer cells increases metastatic potential. Proc Natl Acad Sci U S A. 1997; 94: 3336-40.

74. Fenwick SW, Toogood GJ, Lodge JP, Hull MA. The effect of the selective cyclooxygenase-2 inhibitor rofecoxib on human colorectal cancer liver metastases. Gastroenterology. 2003; 125: 716-29.

75. Yao M, Kargman S, Lam EC, Kelly CR, Zheng Y, Luk P, et al. Inhibition of cyclooxygenase-2 by rofecoxib attenuates the growth and metastatic potential of colorectal carcinoma in mice. Cancer Res. 2003; 63: 586-92.

76. Pai R, Nakamura T, Moon WS, Tarnawski AS. Prostaglandins promote colon cancer cell invasion; signaling by cross-talk between two distinct growth factor receptors. FASEB J. 2003; 17: 1640-7.

77. Birchmeier C, Birchmeier W, Gherardi E, Vande Woude GF. Met, metastasis, motility and more. Nat Rev Mol Cell Biol. 2003; 4: 915-25.

78. Pan J, Yang Q, Shao J, Zhang L, Ma J, Wang Y, et al. Cyclooxygenase-2 induced beta1-integrin expression in NSCLC and promoted cell invasion via the EP1/MAPK/E2F-1/FoxC2 signal pathway. Sci Rep. 2016; 6: 33823.

79. Ko CJ, Lan SW, Lu YC, Cheng TS, Lai PF, Tsai $\mathrm{CH}$, et al. Inhibition of cyclooxygenase-2-mediated matriptase activation contributes to the suppression of prostate cancer cell motility and metastasis. Oncogene. 2017; 36: 4597-609.

80. Ayiomamitis GD, Notas G, Vasilakaki T, Tsavari A, Vederaki S, Theodosopoulos $\mathrm{T}$, et al. Understanding the Interplay between COX-2 and hTERT in Colorectal Cancer Using a Multi-Omics Analysis. Cancers (Basel). 2019; 11.

81. Masferrer JL, Leahy KM, Koki AT, Zweifel BS, Settle SL, Woerner BM, et al. Antiangiogenic and antitumor activities of cyclooxygenase-2 inhibitors. Cancer Res. 2000; 60: 1306-11.

82. Ferrara N, Gerber HP, LeCouter J. The biology of VEGF and its receptors. Nat Med. 2003; 9: 669-76. 
83. Seno $\mathrm{H}$, Oshima $\mathrm{M}$, Ishikawa $\mathrm{TO}$, Oshima $\mathrm{H}$, Takaku $\mathrm{K}$, Chiba $\mathrm{T}$, et al. Cyclooxygenase 2- and prostaglandin $\mathrm{E}(2)$ receptor $\mathrm{EP}(2)$-dependent angiogenesis in Apc(Delta716) mouse intestinal polyps. Cancer Res. 2002; 62: 506-11.

84. Williams CS, Tsujii M, Reese J, Dey SK, DuBois RN. Host cyclooxygenase-2 modulates carcinoma growth. JClinInvest. 2000; 105: 1589-94.

85. Dormond O, Foletti A, Paroz C, Ruegg C. NSAIDs inhibit alpha V beta 3 integrin-mediated and Cdc42/Rac-dependent endothelial-cell spreading, migration and angiogenesis. Nat Med. 2001; 7: 1041-7.

86. Aoki T, Narumiya S. Prostaglandin E2-EP2 signaling as a node of chronic inflammation in the colon tumor microenvironment. Inflamm Regen. 2017; 37: 4.

87. Wang HS, Cao HJ, Winn VD, Rezanka LJ, Frobert $\mathrm{Y}$, Evans $\mathrm{CH}$, et al. Leukoregulin induction of prostaglandin-endoperoxide $\mathrm{H}$ synthase-2 in human orbital fibroblasts. An in vitro model for connective tissue inflammation. J Biol Chem. 1996; 271: 22718-28.

88. Powell DW, Mifflin RC, Valentich JD, Crowe SE, Saada JI, West AB. Myofibroblasts. I. Paracrine cells important in health and disease. Am J Physiol. 1999; 277: C1-C9.

89. Dixon DA, Tolley ND, King PH, Nabors LB, McIntyre TM, Zimmerman GA, et al. Altered expression of the mRNA stability factor HuR promotes cyclooxygenase-2 expression in colon cancer cells. J Clin Invest. 2001; 108: 1657-65.

90. Garg R, Blando JM, Perez CJ, Lal P, Feldman MD, Smyth EM, et al. COX-2 mediates pro-tumorigenic effects of PKCepsilon in prostate cancer. Oncogene. 2018.

91. Zhou P, Qin J, Li Y, Li G, Wang Y, Zhang N, et al. Combination therapy of PKCzeta and COX-2 inhibitors synergistically suppress melanoma metastasis. J Exp Clin Cancer Res. 2017; 36: 115.

92. Zhu M, Zhu Y, Lance P. TNFalpha-activated stromal COX-2 signalling promotes proliferative and invasive potential of colon cancer epithelial cells. Cell Prolif. 2013; 46: 374-81.

93. Zhang F, Subbaramaiah K, Altorki N, Dannenberg AJ. Dihydroxy bile acids activate the transcription of cyclooxygenase-2. JBiolChem. 1998; 273: 2424-8.

94. Glinghammar B, Inoue H, Rafter JJ. Deoxycholic acid causes DNA damage in colonic cells with subsequent induction of caspases, COX-2 promoter activity and the transcription factors NF-kB and AP-1. Carcinogenesis. 2002; 23: 839-45.

95. Wang J, Cho NL, Zauber AG, Hsu M, Dawson D, Srivastava A, et al. Chemopreventive Efficacy of the Cyclooxygenase-2 (Cox-2) Inhibitor, Celecoxib, Is Predicted by Adenoma Expression of Cox-2 and 15-PGDH. Cancer Epidemiol Biomarkers Prev. 2018.

96. Wong RSY. Role of Nonsteroidal Anti-Inflammatory Drugs (NSAIDs) in Cancer Prevention and Cancer Promotion. Adv Pharmacol Sci. 2019; 2019: 3418975.

97. Ng K, Meyerhardt JA, Chan AT, Sato K, Chan JA, Niedzwiecki D, et al Aspirin and COX-2 inhibitor use in patients with stage III colon cancer. J Natl Cancer Inst. 2015; 107: 345

98. Zhu LL, Xu LC, Chen Y, Zhou Q, Zeng S. Poor awareness of preventing aspirin-induced gastrointestinal injury with combined protective medications. World J Gastroenterol. 2012; 18: 3167-72.

99. Cao Y, Prescott SM. Many actions of cyclooxygenase-2 in cellular dynamics and in cancer. JCell Physiol. 2002; 190: 279-86.

100. Punganuru SR, Madala HR, Mikelis CM, Dixit A, Arutla V, Srivenugopal KS. Conception, synthesis, and characterization of a rofecoxib-combretastatin hybrid drug with potent cyclooxygenase-2 (COX-2) inhibiting and microtubule disrupting activities in colon cancer cell culture and xenograft models. Oncotarget. 2018; 9: 26109-29.

101. Hudson M, Richard $\mathrm{H}$, Pilote L. Parabolas of medication use and discontinuation after myocardial infarction--are we closing the treatment gap? Pharmacoepidemiol Drug Saf. 2007; 16: 773-85.

102. Russell RI. Non-steroidal anti-inflammatory drugs and gastrointestinal damage-problems and solutions. Postgrad Med J. 2001; 77: 82-8.

103. Sandler RS, Halabi S, Baron JA, Budinger S, Paskett E, Keresztes R, et al. A randomized trial of aspirin to prevent colorectal adenomas in patients with previous colorectal cancer. N Engl J Med. 2003; 348: 883-90.

104. Bertagnolli MM, Eagle CJ, Zauber AG, Redston M, Solomon SD, Kim K, et al. Celecoxib for the prevention of sporadic colorectal adenomas. N Engl J Med. 2006; 355: 873-84.

105. Bresalier RS, Sandler RS, Quan H, Bolognese JA, Oxenius B, Horgan K, et al. Cardiovascular events associated with rofecoxib in a colorectal adenoma chemoprevention trial. N Engl J Med. 2005; 352: 1092-102.

106. Arber N, Eagle CJ, Spicak J, Racz I, Dite P, Hajer J, et al. Celecoxib for the prevention of colorectal adenomatous polyps. N Engl J Med. 2006; 355: 885-95.

107. Martinez JA, Yang J, Wertheim BC, Roe DJ, Schriewer A, Lance P, et al. Celecoxib use and circulating oxylipins in a colon polyp prevention trial. PLOS One. 2018; 13: e0196398.

108. Harris RE. Cyclooxygenase-2 (cox-2) blockade in the chemoprevention of cancers of the colon, breast, prostate, and lung. Inflammopharmacology. 2009; 17: 55-67.

109. Buchanan FG, Holla V, Katkuri S, Matta P, DuBois RN. Targeting cyclooxygenase-2 and the epidermal growth factor receptor for the prevention and treatment of intestinal cancer. Cancer Res. 2007: 67: 9380-8.

110. Reckamp KL, Krysan K, Morrow JD, Milne GL, Newman RA, Tucker C, et al. A phase I trial to determine the optimal biological dose of celecoxib when combined with erlotinib in advanced non-small cell lung cancer. Clin Cancer Res. 2006; 12: 3381-8.

111. Barry M, Cahill RA, Roche-Nagle G, Neilan TG, Treumann A, Harmey JH, et al. Neoplasms escape selective COX-2 inhibition in an animal model of breast cancer. Ir J Med Sci. 2009; 178: 201-8.

112. Anderson GD, Keys KL, De Ciechi PA, Masferrer JL. Combination therapies that inhibit cyclooxygenase-2 and leukotriene synthesis prevent disease in murine collagen induced arthritis. Inflamm Res. 2009; 58: 109-17.

113. Falandry C, Canney PA, Freyer G, Dirix LY. Role of combination therapy with aromatase and cyclooxygenase-2 inhibitors in patients with metastatic breast cancer. Ann Oncol. 2009; 20: 615-20.

114. Duan DP, Dang XQ, Wang KZ, Wang YP, Zhang H, You WL. The cyclooxygenase-2 inhibitor NS-398 inhibits proliferation and induces apoptosis in human osteosarcoma cells via downregulation of the survivin pathway. Oncol Rep. 2012; 28: 1693-700.

115. Mullins MN, Lana SE, Dernell WS, Ogilvie GK, Withrow SJ, Ehrhart EJ. Cyclooxygenase-2 expression in canine appendicular osteosarcomas. J Vet Intern Med. 2004; 18: 859-65.

116. Naruse T, Nishida Y, Hosono K, Ishiguro N. Meloxicam inhibits osteosarcoma growth, invasiveness and metastasis by COX-2-dependent and independent routes. Carcinogenesis. 2006; 27: 584-92.

117. Urakawa $H$, Nishida $Y$, Naruse $T$, Nakashima $H$, Ishiguro $N$. Cyclooxygenase-2 overexpression predicts poor survival in patients with high-grade extremity osteosarcoma: a pilot study. Clin Orthop Relat Res. 2009; 467: 2932-8.

118. Arjona-Sanchez A, Ruiz-Rabelo J, Perea MD, Vazquez R, Cruz A, Munoz Mdel $C$, et al. Effects of capecitabine and celecoxib in experimental pancreatic cancer. Pancreatology. 2010; 10: 641-7.

119. Howe LR, Subbaramaiah K, Patel J, Masferrer JL, Deora A, Hudis C, et al. Celecoxib, a selective cyclooxygenase 2 inhibitor, protects against human epidermal growth factor receptor 2 (HER-2)/neu-induced breast cancer. Cancer Res. 2002; 62: 5405-7.

120. Dandekar DS, Lopez M, Carey RI, Lokeshwar BL. Cyclooxygenase-2 inhibitor celecoxib augments chemotherapeutic drug-induced apoptosis by enhancing activation of caspase-3 and -9 in prostate cancer cells. Int J Cancer. 2005; 115: 484-92. 